\title{
Daniel Watson
}

Department of American and Canadian Studies, University of Nottingham, Nottingham, United Kingdom

Email: daniel.watson1@nottingham.ac.uk

Daniel Watson is an American Studies PhD student at the University of Nottingham. His research examines how American organised labour intervened in debates over industrial automation during the Cold War. 


\section{Fordism: A Review Essay}

Fordism is a central concept in American labour history. This essay, the first survey of the range of historiographical and sociological approaches deployed to understand Fordism, suggests that Fordism and Americanism are inseparably intertwined. Previous scholarship has emphasised that the technological and managerial efficiency of Fordist practice were a hallmark of twentieth century Americanism. Historians of labour have demonstrated that these aspects manifested as a relentless system of control in the workplace that paradoxically helped to unify worker resistance. Historians of capitalism have tended to used Fordism to refer to an ethos underpinning mid-twentieth century capitalist development marked by a balance between mass production and mass consumption. They identify increased social provisions and class compromise between labour and management as features that made Fordism attractive to states rebuilding their economies following the Second World War. New transnational histories of Fordism have begun to bridge the gap between these two main interpretations to show how Fordist practice and ethos were exported together internationally as part of an ideological project to modernise nations in America's image. This essay concludes by assessing the usefulness of Fordism to historians and suggesting avenues for future research.

Keywords: Fordism; historiography; mass production; capitalism

Marvelling over his company's successful Highland Park plant in 1922, Henry Ford declared that mass production had become the 'new Messiah' (Sward, 1948, p.42). Mass production would certainly not have reached such a status without the blend of new industrial technologies, efficient work organisation, and modern managerial practice realised within Ford's factories. This fusion - Fordism - was instrumental in popularising the automobile, the development of present-day mass production methods, and the emergence of Western consumer capitalism. Despite these contributions, there are few major works solely dedicated to Fordism, with many works relegating discussion of Fordism to a single chapter or infrequently using the term. This has not stopped historians from employing a remarkably 
diverse range of methodologies and approaches to describe and explain Fordism. Histories of Fordism tend to examine the intricacies of the assembly line or provide insight into Fordism's impact on the workplace. In recent years, the transnational turn has resulted in exciting new works analysing Fordism's reception beyond America's borders. A little more than a century since the opening of Highland Park, this review essay will provide the first critical overview of the historiography of Fordism, from the traditional technological and economic analyses to these new transnational perspectives.

Early studies of Fordism often focused on its technological and managerial dimensions. Initial criticism of Fordism following the Great Depression transitioned into positivity during the early Cold War as the Fordist mass production/mass consumption balance were considered central to American superiority. Alongside newer studies of Fordist technologies, the growth of labour history from the 1970s onwards inspired a wave of scholarship in the 1980s on labour-management conflict within Fordist factories, which openly criticised Fordism's repressive elements akin to pre-Cold War studies. Labour historians could continue to find these studies useful in understanding how workers resisted a supposedly benevolent system that tried to stifle their voices, and how their experiences informed future labour struggles. Fordism retains its significance for historians of technology, aiding in understanding the development of American industrial technologies and their heightening cultural profile through improvements to the availability and accessibility of culturally popular products, such as the automobile. ${ }^{1}$

The final few decades of the twentieth century saw historians of capitalism take notice of Fordism. As a term that represented the unity between mass production and mass consumption that had underpinned midcentury American capitalism, historians of capitalism looked to Fordism to understand how neoliberalism had emerged. Fordism remains a useful conceptual marker for economic historians wishing to navigate the complexities of capitalist 
development. Importantly, this perspective on Fordism shows Ford's ideals taking on a greater meaning and significance beyond the original scope of the Ford Motor Company. In recent years, historians of foreign policy have taken interest in Fordism, demonstrating its importance beyond the domestic sphere. Their studies in the 2000s and 2010s focusing on the international expansion of Fordist principles were likely inspired by, and help to explain, twenty-first century economic globalisation. These works should serve as an inspiration for other historians to consider the importance of domestic technological and organisational systems to foreign policy and diplomacy, in America or elsewhere.

These trends have inspired multiple and contested definitions of 'Fordism', but historians of Fordism can be roughly divided into two definitional camps. The most commonly accepted definition is that Fordism is a system of mass production combining the new technological innovations of the early twentieth century which accelerated the pace of manufacture, particularly the assembly line, with a managerial ethos encouraging greater efficiency in the organisation of work. This definition sees Fordism's technological innovations as driven by the concept of maximal production at a minimal cost, achieved by creating high volumes of a limited series of standardised products. Those using this definition generally hold Fordist management responsible for a deskilling and homogenisation of the workforce, reducing workers to cogs in the well-oiled machine that was the assembly line.

The second definition of Fordism sees it as a phase of capitalist development taking place several decades after the heyday of the Ford Motor Company. Often used to mark the period from approximately 1945 to the mid-1970s, this definition sees this period of capitalist development as a realisation of the vision that Henry Ford aimed to achieve in the first decades of the twentieth century. As a result, they associate Fordism with a careful balance in the American economy between mass production and mass consumption and an increase in the wage rate and social provisions for workers. Fordism's death knell, proponents of this 
definition argue, came with the processes marking the transition to neoliberalism in the mid1970s, namely deregulation, decentralisation, and deindustrialisation.

These disparate but broad definitions illustrate that Fordism intersects many fields. The first definition relates more to the practices of the Ford Motor Company, whereas the second definition is the true Ford 'ism', the ethos that outlived its creator. Although Fordist practice and ethos influenced one another, works using these definitions often speak past each other. The reason for this could be the differing treatment of Fordism between users of each definition. Managerial and technological approaches, building on a larger body of work on Ford, lend themselves to rigorous and lengthy treatments of life in Ford's factories. In comparison, there are few monograph-length studies of Fordist capitalism. Instead, Fordism is often relegated to a chapter-length discussion in broader works on the history of capitalism, or simply included as a term without meaningful dissection. The new transnational histories have begun to rectify this, bridging the gap between the two definitions by showing how Fordist mass production methods and the principles of Fordist capitalism were exported internationally.

Parallel to these definitions are four main approaches to the relationship between Fordism and American life. Some works see the interaction between Americans and Fordism as taking place on a purely technological level, such as workers grappling with the assembly line firsthand or consumers enjoying the fruits of these new technologies. Others see Fordism as a managerial system distinguished by a combination of scientific management methods and a focus on using company resources and the conditions of factory life to improve the lifestyle and attitude of workers, whilst simultaneously driving workers to maximise productivity. Works taking this perspective often see the interaction of the American people and Fordism as juxtaposed between scheming Fordist managers and discontented workers. Those defining Fordism as a phase of capitalism suggest that Fordism provided the 
framework that prefigured American economic, social, and political interactions between producers and consumers. Finally, recent analyses of Fordism's international impact see the interactions between the American populace and Fordism as taking place beyond the material level, demonstrating that Americans saw Fordism as a global phenomenon that they believed afforded the United States a hegemonic position in the wider international community, and that on occasion this reverence towards Fordist capitalism and production methods was reciprocated by the countries that chose to adopt it. Central to all of these interpretations is the relationship between Fordism and Americanism, with all approaches converging on the consensus that Fordism was seen as quintessentially 'American' by international observers and the American people, and that it formed an essential component of American life during the early twentieth century. Such an association was ironic, considering Fordism's corporatedriven consumer capitalism was so far removed from the small-scale, laissez-faire capitalism central to the American way of life during the early Republic.

This examination of the literature on Fordism divides the scholarship into four sections in keeping with these trends: 1) works on Henry Ford himself, 2) works examining Fordism as a technological and managerial practice, 3 ) works viewing Fordism as a phase in capitalist history, and 4) recent works on Fordism's global implications.

The earliest literature on Fordism focused on its namesake's career and influence. In his biography of Henry Ford released in 1948, shortly after the industrial mogul's death and with memories of the Great Depression fresh in mind, Keith Sward offers a sober assessment of Ford's character and the impact of Fordism. ${ }^{2}$ Far from being swayed by Ford's impressive achievements, Sward's biography presents Ford, in all his stature, as a deeply flawed character. Although Ford was blessed with 'daring, ambition, mechanical genius, inexhaustible energy and a capacity for undivided attention', he did not appear a capable leader 'in appearance and manner'. After 1914, Sward holds, Ford's ego inflated due to 
surprise over his past successes, leading him to believe he was 'the man of destiny'. Sward suggests that these attributes of Ford's character led to his undoing, as his obsession with his industrial plants led him to 'drive his staff with an ever more imperial hand'. He is attentive to the effects of the Fordist system of mass production on the workforce, maintaining that the constant shifting of workers between jobs to staff new mechanised processes led to Ford's line workers feeling 'that [their] status was gone', noting that many lost interest in their jobs as they became increasingly 'dull and repetitive' (Sward, 1948, pp.40, 43, 47, 63). In stark contrast, Allan Nevins and Frank Ernest Hill heap generous praise onto Ford's life in their three volume biography of Ford published at the height of the Cold War, the first significant scholarly biography of Ford following his death. Aiming to celebrate American capitalism, Nevins and Hill resort to hagiography on occasion, as in their reference to Ford as an 'industrial angel, bringing light and order to dark places'. As a result, they view the principles underpinning Fordist management as similarly benevolent. The oppressive atmosphere at Ford's famous River Rouge plant, which led to workers experiencing symptoms of anxiety that they nicknamed 'Forditis', is attributed by Nevins and Hill to be the result of tightly packed plant organisation rather than managerial practice (Nevins \& Hill, 1957, pp.18-19, 248, 296-297).

Nevins and Hill's assessment of Ford's 'Americanization' program, designed to imprint his personal conception of Americanism on his large immigrant workforce, is overwhelmingly positive. Although it did create animosity among employees, they contend that 'far greater trouble would have flowed from the neglect of [Americanization]'. Their language suggests that Ford civilised his migrant workforce by 'inducing them to accept simple household standards' leading to 'a manifest elevation in moral standards' (Nevins \& Hill, 1957, pp.338-339). Although many of the arguments made by Nevins and Hill appear suspect when compared with Sward's observations, their work demonstrates that Ford's and 
Fordism's association with Americanism was evident to contemporaries. Almost half a century after Nevins and Hill's work, Steven Watts's biography of Ford offers a similarly positive perspective on how Ford - and, by extension, the Fordist system - became so famous. Watts's analysis mostly portrays Ford as a titanic figure who shepherded the American people through the turbulent turn of the twentieth century marked by 'the emergence of consumer capitalism, mass culture, bureaucracy, and the corporate state'. By 'drawing upon consumerism, mass culture, and populism', Watts argues, Ford advocated an American way of life that would help others adjust to this new capitalist modernity. His push for consumption to become 'the real standard of happiness and achievement in one's work life in modern America' and the realisation of this vision through his 'innovations in mass production', Watts emphasises, led Ford to gain a level of fame and influence 'unsurpassed in American life'. This level of popular support indicates that the general public identified with Ford's American values even as his anti-Semitism and anti-unionism reared their ugly head in his populist stance (Watts, 2005, pp.xi-xiii, 158, 249, 295, 534). It is ironic, then, that Fordism became the moniker for a postwar period when Catholics, Protestants, and Jews joined together in a tolerant Americanism, and a political economy marked by a high union density and a strong welfare state.

Ford's fame and influence would hardly have reached their heights without his embrace of new technologies that facilitated mass production and made his Highland Park plant, in Watts's words, 'the site of a miracle' (Watts, 2005, p.135). David Hounshell offers an impressive analysis of Fordism's technological dimension in his monograph examining the development of the American manufacturing industry from 1800 to 1932 to trace the successive technological innovations that led to the birth of mass production. Culminating in the adoption of Fordist methods, Hounshell equates Fordism with 'mass production', its terminological replacement after 1925, defining it as a break with past manufacturing 
methods by referring to it as the start of 'an entirely new epoch in the manufacture of consumer durables in America'. He alludes to the effect this revolutionary development had on America's global standing, concurring with Nevins and Hill that Ford's production engineers created 'a lever to move the world'. Ford's contribution to the evolution of production processes, Hounshell argues, was the 'highly mechanized and subdivided manufacturing operations' embodied by the assembly line. Although Hounshell acknowledges the 'severe demands' of the assembly line on the labour force, he blames the technology of the line for this, rather than the managerial decisions behind its implementation. He sets a firm limit on his periodisation of Fordism, stating that Ford's method of mass producing a standardised product was 'dead' by 1926, replaced by 'flexible mass production' capable of adapting to the changing tastes of consumers by diversifying the range of products. However, the technologies and strategies underpinning the purportedly 'inflexible' Fordist system persisted in this new era which suggests that the transition was not as clean-cut as Hounshell proposes. Despite these shortcomings, his work offers a compelling exploration of the components of Fordist production: 'highly mechanized production, moving line assembly, high wages, and low prices on products' (Hounshell, 1984, pp.9-13, 220).

Scholarly efforts to define Fordism as a production system have sparked debate over the extent to which Fordism was inspired by Taylorism, an ostensibly similar theory of industrial production and organisation. ${ }^{3}$ Although both theories had the same end goal of maximising the efficiency of industrial production, they proposed different strategies to achieve this. Taylorism aimed to make the movements of workers as efficient as possible while retaining the complexity of the task at hand. For example, this could be achieved by providing detailed instructions to workers on how to perform their tasks. Wage bonuses were awarded for faster work. Therefore, Taylorism essentially aimed to make workers machinelike in their efficiency. Fordism instead proposed that productive efficiency was best 
achieved by mechanising the flow of production, simplifying the individual tasks performed by workers, and removing workers from the equation at certain points in the process. Unlike Taylorism, Fordism's use of technology - the assembly line in particular - took the transportation of materials and works in progress out of the hands of workers entirely. Instead of relying on workers to pace themselves through monetary incentives, Fordism relied on the assembly line to dictate the pace of work, making piecework rates obsolete.

Hounshell acknowledges the similarities between Fordism and Taylorism, namely that both systems utilised standardised work routines based on studies of the time taken and number of motions required for workers to perform tasks. However, he argues that Taylorism did not contribute significantly to Ford's assembly system based on Ford's personal testimony and an essential philosophical difference between the two systems. Whereas Taylorism sought to revise and improve the efficiency of labour organisation and the individual worker's lot under the assumption that production technology would remain constant, Fordism mechanised work processes and found workers that could keep pace with the demands of ever-improving machines (Hounshell, 1984, pp.249-252). Contrarily, Stephen Meyer, in his excellent monograph on Fordist managerial methods and how these affected industrial workers, argues that Ford managers and engineers 'followed the proposals of Frederick W. Taylor' when devising Fordism. He posits that the influence of Taylorism was impossible to escape as Ford architects were working within a 'rapidly evolving tradition of American technological innovation', and hence they must have followed the general principles of Taylorism - an essential part of that tradition - even if they did not intend to emulate it (Meyer, 1981, pp.11, 18-21). Meyer's case is persuasive; after all, it is easy to explain Ford's personal claim of Taylorism's irrelevance to Fordism as self-aggrandisement on Ford's part. Despite Hounshell's identification of philosophical difference between Fordism and Taylorism, the similarities between the two systems reinforce Meyer's argument that Ford 
planners were adding their own improvements to a traditional body of knowledge on industrial production, to which Taylorism was a recent addition.

Similarly, David Nye weighs in on the tendency to view Taylorism and Fordism as distinct and successive historical stages in his history of the assembly line. Nye argues that the sharp differences between the two systems have led to this interpretation. However, he contends that industrial production did not move through historical stages so distinctly, but that both methods essentially coexisted. Whereas assembly line production was suitable for many products, certain specialty products required artisanal or Taylorist approaches which an evolutionary mode of manufacturing might suggest had already been superseded (Nye, 2015, pp.34-36). Nye's analysis crucially speaks to the importance of Fordism as a system of industrial production, but one that was not as monolithic as its popularity might suggest. His work is notable for its close attention to the social impact of the assembly line on American workers despite its ambitious remit of the entire twentieth and early twenty-first centuries. $\mathrm{He}$ emphasises the concerns of postwar commentators that the assembly line subjected workers to a mentally deadening homogenisation of work to a low skill level with little to no hope of advancement, and suggests that workers shared their discontent at these developments (Nye, 2015, pp.147-148, 152-153). Meyer also notes worker resentment towards their new deskilled line jobs. Their work no longer required mental acuity, only the stamina to withstand physical monotony (Meyer, 1981, pp.38-42, 52).

Nye's work shares with Hounshell's monograph an awareness of the wider cultural impact of the assembly line in American society beyond these common criticisms. He makes a remarkable connection between the popularity of the assembly line and the trend towards synchronicity in performance arts as well as noting a plethora of linguistic and lyrical references to the assembly line from around 1910 to 1940 (Nye, 2015, pp.56-59). Likewise, David Gartman examines how Fordism influenced architecture throughout America and 
Europe. He argues that the popularity of Fordist design in Europe was due to the mass produced look (standardised and basic designs without ornamentation) becoming synonymous with a free and democratic modernity, one that was quintessentially American (Gartman, 2009, p.12). However, these authors illustrate that the association of Fordism with Americanism was often a double-edged sword. Hounshell draws attention to the works of Aldous Huxley and Charlie Chaplin representing Fordist mass production as symbolic of the problems of the modern world, particularly in their emphasis on the potentially authoritarian nature of a society subordinated to mass production (Hounshell, 1984, pp.316-321). Gartman notes the growth of pop art challenging Fordism through criticisms of rationality and technology, arguing that the desire for Fordist housing evaporated as workers with a rising standard of living at midcentury wished for variety over uniformity in architecture (Gartman, 2009, pp.257, 265). The forays made by Nye, Hounshell, and Gartman into Fordism's cultural influence are welcome additions to a field in which cultural histories of Fordism are lacking, and they serve to reinforce the notion running throughout the historiography that, whether lauded or criticised, Fordism and Americanism were seemingly inseparable for contemporaries.

Interested observers of Fordism in America and elsewhere looked to Fordist management to understand why it had become so integral to Americanism. Stephen Meyer explores Fordist management and flags up Nevins and Hill's problematic apportion of blame for the repercussions of the Fordist managerial system. As one of several labour historians analysing Fordism in the 1980s, he argues that 'conscious control of labor and labor processes' was central to the Ford industrial system. He critiques the assessment of technology made by Hounshell and Nevins and Hill, emphasising that the development and implementation of technologies are socially determined by decisions about 'the nature of workers and work processes' made by managers. Defining the Fordist system as one of social 
control that combined 'the traditions of scientific management, welfare work, and personnel management' with the intention of transforming the 'personal and social attitudes' of workers, Meyer suggests this same focus led to its eventual downfall, as Ford was ultimately unable to fully discipline and control his labour force (Meyer, 1981, pp.4-7). Unlike Nevins and Hill's optimistic interpretation of Ford's motives behind his high wages, Meyer persuasively argues that Ford's Five Dollar Day wage standard and his so-called 'profit sharing plan' (which simply withheld a portion of wages between the daily wage and five dollars, denoted as 'profit', from workers who did not obey company rules), alongside the efforts of investigators in Ford's 'Sociological Department' tasked with prying into the private lives of workers, were mechanisms that allowed Ford managers 'to control the lives and the behavior of Ford workers'. The Fordist system's combination of scientific management with methods of 'industrial betterment' seeking to socially and culturally influence workers within and beyond the workplace laid the foundations for modern personnel management and welfare capitalism, linking Meyer's work with those on Fordist capitalism (Meyer, 1981, pp.96, 110-111, 146147).

Meyer offers a fascinating exploration of Ford's systems of control and 'industrial betterment' and their connections with Americanism. He argues that managers believed that the assimilation of immigrant workers into American life was essential to maintain discipline in the workplace and to ensure that workers adapted adequately to the factory environment. Indeed, Meyer maintains that Americanism and Fordism were interwoven, and that Ford's conception of Americanism - and how his employees should embody Americanism changed between the Progressive Era and the First World War. Whereas prior to the war Ford's vision of Americanism involved rewarding his workers with a decent 'American' standard of living replete with material comforts, during the war his Americanism took on a more negative definition, as Americans simply became those who did not criticise American 
institutions or actions and certainly did not let previous national ties get in the way of their loyalty to America (Meyer, 1981, pp.149, 170, 183-185, 193-194). Meyer's study provides important insight into how Ford and his managerial staff understood Americanism and illustrates how their dedication to realising their vision of Americanism eventually undermined their desired paternalist image among their workforce. Building on Meyer's study, Richard Coopey and Alan McKinlay testify to the controlling intent behind the Fordist system. They use Foucault's work on the necessary connection between power and knowledge as a model with which to investigate supervisory arrangements in the Ford Motor Company, arguing that the tactics of Ford's supervisors did not create a system of surveillance, but rather 'a system of terror' upheld by foremen. The fear that foremen struck into workers through physical and symbolic confrontation on the shopfloor during the interwar period, with the River Rouge being a particularly egregious example, was not Foucauldian according to Coopey and McKinlay, as there was no attempt to collect knowledge about 'worker demographics, competencies, or motivations' in the process of surveillance (Coopey \& McKinlay, 2010, pp.108, 110-114).

They track a shift in the Fordist regime from this 'violent, monarchic' rule to a 'more stable disciplinary' alternative in the postwar period, a shift from a system of power without knowledge to a 'modern disciplinary system that combined power and knowledge'. This change happened not specifically due to strategic choices from above, but rather as supervisors gradually began to shy away from harsh discipline, which subsequently influenced the strategic direction of the company (Coopey \& McKinlay, 2010, pp.115-116, 119-121). Coopey and McKinlay's study speaks to the importance of examining how managerial directives and company ethos shape and are shaped by ground-level managerial staff. Their analysis importantly illustrates the centrality of control and discipline to the Fordist system throughout the early twentieth century, demonstrating how Ford's initial 
vision was processed and carried out by foremen with a brutality likely unintended by Ford himself. Of course, new technological developments played a unique role in reinforcing managerial control, as David Gartman convincingly argues in his monograph on the development of the labour process in the American automobile industry from 1897-1950. Like Meyer, Gartman emphasises that the choice of industrial techniques, both technological and organisational, are the result of partisan social processes, and that 'social maladies' created by capitalist work organisation are 'the intended results of industrial means chosen to further private interests'. Gartman's standpoint emerges from his professed Neo-Marxist perspective, an interpretation of Marxism arguing that class conflict is the driving force for new production technologies and organisational techniques. This leads into Gartman's central argument, namely that managers and capitalists used technology and organisation to quash the resistance of a recalcitrant workforce (Gartman, 1986, pp.1-3).

Opposing Harry Braverman's argument that technology is inherently neutral and warped by capitalists to repressive ends, Gartman instead posits that some organisational and technological aspects of industrial production can be termed 'nonrepressive control', such as essential processes of coordination and technologies that directly increase labour productivity. He contrasts this term with 'repressive control': methods that also aim to increase productivity, but those engineered by capitalists to extract more labour from workers than they would voluntarily offer. He emphasises that most production techniques combine both approaches (Gartman, 1986, pp.5-9, 17). Gartman bases his criteria for categorising production techniques on a top-down analysis, which creates potential problems with his argument. The experience of workers are surely an important determinant of whether a production technique is repressive or not, and if nonrepressive techniques on paper are viewed as repressive by workers then these examples would problematise Gartman's analysis. His later discussion of automatic machines also misses the potential for worker repression to come from attacks on 
their identity. Although Gartman mentions that deskilling work 'puts the fear of unemployment' into workers, he does not account for the automatic machine as a threat to workers self-identifying as an artisan or specialist, who would see machines usurp their identities (Gartman, 1986, pp.114, 118-122). For this reason, from the worker's perspective automatic machines could also have been repressive control measures from their initial implementation. Similarly, David Gordon, Richard Edwards, and Michael Reich's study reinforces Gartman's argument that control over workers was a central motive behind Fordist management. Their work aims to understand the roots of late twentieth-century divisions in the US working class by examining how workers responded to institutional and economic changes throughout the late nineteenth and early twentieth centuries. They argue that mechanisation began to be driven by a desire for managerial control during the American Civil War, which saw the application of new technologies to the production process in order to reduce employment of skilled workers, deskill available jobs, create homogeneity of work tasks and working conditions, and to regulate the pace of production. Although Ford may have upgraded these early systems with his assembly line, the line was not a decisive turning point in itself but rather a culmination of the desire for labour homogenisation that had developed during the Civil War (Gordon, Edwards, \& Reich, 1982, pp.113-115).

As a result, Gordon, Edwards, and Reich hold that the assembly line was not the only manifestation of Fordism's philosophy of control, as they, like Nevins and Hill, point out the changes in plant design towards fragmenting plant activities and the use of wage incentive schemes to encourage competition among employees which combined with the assembly line to form the 'drive system'. Unlike Nevins and Hill they firmly place the blame for these developments on managerial actions. Their study, however, suggests that the drive system helped trigger the Great Depression by creating a disparity between worker wages and labour productivity, and therefore was subsequently abandoned post-Depression in favour of 
'segmenting' labour using new corporate rules incentives and collective bargaining agreements. Their section on this process of segmentation suggests that control over workers continued through predominantly 'bureaucratic control' methods as opposed to technical ones and posits that the labour organising drives of the 1930s were inspired by the harsh conditions of the drive system (Gordon et al., 1982, pp.131, 139-140, 164, 188-189). They argue that the prevalence of the drive system led to wider trends in management towards mechanisation, the increasing use of foremen to supervise workers, and the corresponding reduced reliance on skilled labour, but they do not refer to these features explicitly as 'Fordism', instead attributing them to a wider historical phase in the development of the US working class. They call this phase 'homogenisation' as these developments contributed to the reduction of jobs to a 'common, semiskilled operative denominator'. By subtly nestling these attributes of Fordism into this overall transformative stage, Gordon, Edwards, and Reich suggest that Fordism is less important to changes in the working class and managerial tactics than the general process of homogenisation, the chronological beginning of which, they argue, predates Fordism. Subsequently, they hold that the assembly line was far from a turning point, but rather 'a culmination of the successive movements towards homogenizing mechanization that had spread since the Civil War' (Gordon et al., 1982, pp.2-3, 14-15, 131, 145-146).

Similarly, James M. Wilson and Alan McKinlay argue for the reduced importance of the assembly line to the history of American mass production. They maintain that it is necessary to view Ford's innovations as part of wider trends towards the 'professionalisation of American engineering' and the 'rise of large-scale management'. Indeed, they emphasise that standardisation of components and assembly methods was not unique to the Fordist system, positing that the wider managerial changes within the Ford Motor Company such as 'eliminating outside contracting, improving component design and using new materials, and developing more extensive administrative controls' were more significant (Wilson \& 
McKinlay, 2010, pp.761-762). Together with Gordon, Edwards, and Reich, Wilson and McKinlay assess the assembly line only in terms of its effect on Ford's productivity akin to earlier histories of Fordism - to which management certainly played an equal if not more significant role - without considering its impact on Ford's employees and the wider American populace. However, based on the newer contributions to the scholarship on the cultural impact of Fordism, it appears that many Americans in the early twentieth century would disagree with these authors' suggestions that the assembly line lacked importance. Even in the case of Ford Motor Company workers, who would be more aware of the effects of new managerial methods on their productivity, the assembly line remained an important physical manifestation of Fordism towards which they could direct their ire. Even if the elements that made up Fordism were not unique to the Ford Motor Company itself, it does not diminish their importance or effectiveness in the automobile industry that led to Fordism becoming so enduring in the American consciousness. Perhaps the popularity of 'Fordism' can be best viewed as a way for contemporaries to associate a name with these wider changes and create an immediate association between these developments and the early twentieth century brand of Americanism into which Fordism was rapidly becoming subsumed.

Wilson and McKinlay also call into question the intent behind the Fordist system in their work, arguing that Ford's innovations were not motivated by 'a drive for control over labour nor...a neutral search for efficiency', instead suggesting that Ford's intent was to create a system that would best allow for effective work organisation, high worker motivation, and efficient organisational performance. They challenge the assumption that high labour turnover in the Ford Motor Company 'reflected an inhospitable working environment', instead arguing that these levels of turnover resulted from internal company restructuring to streamline operations and Ford's tactic of constantly altering the size of the workforce to ensure that the current level of demand for their automobiles could be met by the minimum 
number of staff (Wilson \& McKinlay, 2010, pp.761, 765-768). Wilson and McKinlay's assessment of the level of turnover results from their statistical analysis centred on productivity, as does their conclusion on the impact of the assembly line, but this viewpoint runs counter to the dominant trend in social and labour histories towards seeing the monotony of the assembly line and strict managerial control as the central causes of high labour turnover. David Gartman persuasively argues that the high rates of turnover cannot be solely attributed to fluctuations in the labour market, but rather that new technologies and methods of work organisation resulted in workers resigning as an act of protest, refusing to work jobs that they viewed as degrading. He develops on this point by noting the level of subtle worker resistance within Ford's factories, such as workers manipulating time-study analyses by working deliberately slowly to ensure they would receive high work rates without overworking themselves (Gartman, 1986, pp.152-157). Gordon, Edwards, and Reich concur with Gartman's analysis, emphasising that the resistance of industrial workers in the 1930s was directed towards new mechanised technologies and organisational methods (Gordon et al., 1982, p.178). It is possible to reach a middle ground between Wilson and McKinlay's conclusions and these works if the fluctuating workforce level is viewed as contributory to worker resentment at the 'inhospitable working environment' in Ford's factories, a connection which Wilson and McKinlay overlook.

Alongside their investigations of how workers resisted changes to their occupations as a result of Fordism, labour historians have examined the repercussions of these changes on workers' capacity for effective organisation. Mike Davis's noteworthy work on the development of the US working class implicitly argues that Fordism might have been intended by managers to keep workers divided and powerless, but instead it inadvertently unified workers in opposition to it. Davis asserts that Fordist mass production '[set] the stage for the emergence of the $\mathrm{CIO}$ and the rebirth of industrial unionism'. Periodising the labour 
uprising that led to the creation of the CIO from 1933-1937, Davis posits that this uprising was not primarily concerned with wages or working hours. Instead, he argues that their grievances were non-economic. Workers turned to activism in the hopes that it would allow them to overturn 'the petty despotism of the workplace', symbolised by the brutality of the foremen and the 'inhuman pressures of mechanized production lines'. Because most industrial workers were experiencing these conditions, the $\mathrm{CIO}$ was able to form and gain political clout despite its various constituting unions mobilising different sections of the working class (Davis, 1986, pp.51-56). In line with Davis's analysis, Gartman emphasises the paradoxical nature of Fordism in creating homogeneity among worker viewpoints and a desire for collective activism, the exact opposite of what managers had intended. He suggests the unionisation efforts of auto workers in the 1930s were primarily focused around opposing the managerial tendency towards speeding up the pace of work. Auto workers shared this experience of being 'sped up' at the hands of dictatorial capitalists and managers, and their common plight forged them into a collective political entity. Indeed, Gartman emphasises that it was those workers that faced deskilling and speed-up that became the most active and militant in the union movement (Gartman, 1986, pp.259-261).

Mark Rupert's excellent monograph examining the centrality of mass production methods to the establishment of American global hegemony in the twentieth century similarly attributes the rise of unionism in the early twentieth century to the influence of Fordist methods. However, unlike Gartman's or Davis's studies, Rupert argues that Fordism did not merely cause workers to rebel against the system or their managers, but rather led to unions taking aim at the managerial vision of Americanism that Fordism represented. Rupert suggests that Ford managers believed in a vision of Americanism which saw management and workers cooperating in a common enterprise for the greater prosperity of the nation. This philosophy extended to the company's efforts at 'Americanizing' new immigrant labourers 
through classes offered at the Ford English School, in the hopes that the ethnic and national ties of migrant workers could be overridden by a shared American identity. However, the shift towards more coercive and openly brutal management methods in the Ford factories following the First World War - and the intrusive activities of Ford's Sociological Department spies - led to workers internalising the classical liberal values of privacy and autonomy of the individual to critique Ford's paternalistic vision of Americanism. Rupert asserts that the United Auto Workers opposed Ford's industrial regime in 1937 by tarring it as 'un-American', proclaiming that they would bring about a new vision of Americanism: an industrial democracy where the individual rights and autonomy of workers would be safeguarded. Reinterpreting the language and symbolism of Americanism, unions stood in opposition to Fordism, and this decision attracted workers across the ideological spectrum (Rupert, 1995, pp.117-119, 124-125, 139-140, 165). Rupert's work persuasively demonstrates union engagement with broader political and ideological concepts to oppose managers, rather than assuming, as similar analyses often do, that unions solely relied on the testimony of workers' own experiences to buttress their arguments.

Davis's, Rupert's, and Gartman's arguments for increased labour homogenisation makes the delay in labour organisation seem all the more puzzling. Gartman offers an explanation for this delay derived from the state of the job market. Prior to the Great Depression, workers tended to leave plants if they disliked the working conditions with the expectation of finding work elsewhere. With labour market conditions shifting towards a surplus after the Depression, discontented workers were unable to sacrifice their jobs and escape so easily, fomenting a rising desire to change their situations. In addition, Gartman argues convincingly that the contradictions of the Fordist system were just as integral to the rise of unionisation as the context of the Great Depression. Large automotive factories employing masses of workers united in their experience of mechanisation and rationalisation 
were ripe for labour communication and organisation, despite managerial efforts to fragment the working class through wage differentials, among other methods (Gartman, 1986, pp.261263). Davis's argument complements Gartman's view, suggesting that, unlike the white male working class in European nations, America's white male working class had no need for a unifying struggle for suffrage and civil liberties. Divisions between these workers and those who were disenfranchised, such as African Americans, immigrants, and women, made it difficult for workers to organise during the early years of Fordism. Indeed, Highland Park had a majority immigrant workforce in 1914. As a result, their 'ethno-religious alignments' proved an insurmountable barrier towards the creation of a unified working class culture in the late nineteenth and early twentieth centuries (Davis, 1986, pp.3, 10-11, 15-16, 40-41, 46-47). The observations of Gartman and Davis add another dimension to Gordon, Edwards, and Reich's study, helping to explain why workers, despite going through a process of homogenisation and beginning to resist Fordism, were still unable to coalesce into a formidable collective until the 1930s. Viewed alongside studies of Fordism's managerial elements, it demonstrates that it was not only the fault of managerial organisation but also the divisions among workers that stifled opposition to Fordist methods during the first few decades of the twentieth century.

As the twentieth century progressed, workers had to contend with Fordism's effects on the framework of capitalism, a topic which Mike Davis analyses in his monograph examining how the wage relation developed throughout the nineteenth and twentieth centuries. Fordism, Davis suggests, represents the third - and comparatively most socialised - phase of this development spanning from 1940-1975. He charts the path of capitalism to this point beginning with the period of 'competitive capitalism' from the Civil War to the Great Depression of the 1890 s, marked by the formidable power of paternalistic employers backed by 'the weight of a petty-bourgeois electorate' that stifled all attempts at labour organisation or organised welfare provisions. Davis argues that this period transitioned into 'unorganized 
corporate capitalism', lasting from 1900 to between 1935 and 1940. In this stage, the rapid growth of corporations and new systems of mass production meant that previously aloof employers needed to ensure 'some measure of voluntary intellectual collaboration by the workforce' through a blend of coercion and consensus, a factor that Ford recognised and actualised in his Five Dollar Day system. Developing on the standards set by Ford's welfare provisions, the immediate postwar years provided the conditions for transition into the Fordist - or 'organized corporate' - phase of capitalism, namely the National War Labor Board institutionalising collective bargaining and grievance procedures, the Wagner Act allowing for 'the consolidation of the existing frontier of union organization' and the 1950 General Motors agreement ratifying 'private supplementation of pensions and health insurance', leading to provisions that guaranteed the wage level. This increase in social provisions and opportunities for labour organisation took place alongside the postwar boom, which saw the expansion of North American, Western European, and Japanese markets under the central Fordist tenet of a close linkage between mass consumption and increasingly efficient mass production (Davis, 1986, pp.105-108, 111-112).

The spread of Fordism around the world following the Second World War, Davis suggests, was only possible due to the growth of the US economy generating rising international interest in Fordist economic principles. This resulted in Fordism's transformation into the 'economic trajectory of American hegemony' after the adoption of Fordism by European and Japanese economies led to their postwar recovery. Davis argues that the economic dimensions of US hegemony, supplemented by a 'unified imperial military and state system' resulted in the near '"Americanization" of Europe' during this period, a historical era in which Americanism and democratic capitalism were synonymous. Writing during Ronald Reagan's presidency, Davis notes that the transition to neoliberalism under Reagan resulted in the dismantling of Fordist capitalism, due to a movement by US 
corporations away from consumer durables and towards high profit sectors, and the shift in the centre of technological development from the Atlantic to the Pacific, among other factors. Alongside these trends, Davis notes the simultaneous breakdown of the strategic gains and wage patterns that were representative of the Fordist period (Davis, 1986, pp.102-103, 190, 195, 233). David Harvey's work on the origins of and reasons behind the pervasive spread of neoliberalism complements Davis's study by identifying similar reasons behind the transition from Fordism to the new global hegemony of neoliberalism. Harvey refers to neoliberalism's predecessor as 'embedded liberalism', which is essentially synonymous with Fordism. Indeed, the features of 'embedded liberalism': a focus on full employment, state economic growth, the persistence of a labour-management 'class compromise', and the construction of a welfare system are those same hallmarks of Fordist capitalism discussed by Davis. Similarly, Harvey's analysis of the breakdown of 'embedded liberalism' is in line with Davis's observations, particularly that neoliberalisation represented not only a potential method to overturn rampant stagflation but one through which economic elites could reorganise international capitalism to better their own circumstances and deprive labour of the power it enjoyed during the Fordist period (Harvey, 2005, pp.3, 10-12, 15, 19).

Harvey and Davis offer an apt analysis of how Fordism's integration with Americanism facilitated the predominance of economic systems modelled after America on the world stage and the process through which this system was abandoned in favour of neoliberalism. However, Nick Heffernan's work instead sees this transition away from Fordist capitalism as a shift from Fordism to 'Post-Fordism'. As with Davis's monograph, Heffernan defines Fordism broadly as the organisation of Western economy, society, and culture around a balance between mass production and mass consumption between 1945 and the early 1970s. It is the inclusion of 'culture' into his definition of Fordism that influences the use of 'PostFordism' as a name for Fordism's successor. Alongside the features associated with 
neoliberalism by Harvey and Davis, such as 'decentralisation, demassification, and the demise of Fordist standardisation', Heffernan goes beyond the social and economic indicators of transformation noted by these scholars to include the cultural shifts associated with postmodernism. His work resonates with those studies focusing on the managerial aspects of Fordist mass production and their effects on labour by adopting a self-confessed Gramscian definition of Fordism, one which sees Fordism as a peculiarly American social and economic system that aimed to dampen capitalism's previously unregulated competition and class conflict, resulting in an 'institutionalisation of the class struggle'. This definition sees the creation of a Fordist 'planned economy' as predicated on a 'social and cultural transformation' to create the necessary level of consent among wage-earners to facilitate Fordism's establishment (Heffernan, 2000, pp.3-5, 212). Heffernan's work is a welcome addition to the scholarship on Fordism in its discussion of Fordism's cultural dimensions. The integration of postmodernist culture into his definition of Fordism should serve a useful framework for scholars wishing to develop on the glimpses into Fordist culture offered by Nye, Hounshell, and Gartman.

Heffernan also pays close attention to the international impact of Fordist capitalism in his work. He argues that the Second World War set the stage for a spatial realignment of the world's economic and political relationships as more countries progressively adopted elements of Fordist capitalism. It was the consolidation of the Fordist relationship between mass production and mass consumption in the United States that kept it afloat among its 'warravaged' allies, resulting in the centre of industrial capitalism shifting to the United States and affording it a hegemonic position in global affairs. However, Heffernan goes a step further, arguing that this process led to the conscious export of Fordism to the world's periphery as a method of revitalising the Western European and Japanese economies. He notes the necessity of expanding Fordism to ensure America's position as the industrial capitalist core of the 
world during the Cold War, and how this led to foreign policy planners and modernisation theorists turning an imperialistic eye to newly decolonising nations in the hope of creating an 'American-Fordist version of empire'. Heffernan emphasises that it was this desire to expand to fulfil geopolitical aims that led to Fordist capitalism's undoing. The recovery of Western European and Japanese economies meant that their products were able to compete with American goods, undermining America's dominant economic position (Heffernan, 2000, pp.171-175). Heffernan's work persuasively demonstrates the importance of Fordism as an ideological tool in American Cold War foreign policy, illustrating how Fordism's connection to Americanism was consciously manipulated to encourage the adoption of American democratic capitalism in newly developing and recovering economies. His argument, viewed alongside Harvey's and Davis's, illustrates that Fordism had become a global phenomenon, a status quo that many wished to preserve.

Indeed, Henry Ford and his managers were so adamant that Fordism embodied Americanism that they sought to export it to other countries, one of which was Brazil. Greg Grandin examines the activities of the Ford Motor Company's Brazilian settlement known as Fordlandia in his excellent monograph, the standout work among other twenty first century transnational histories of Fordism. Grandin's analysis of the motivations behind Fordlandia's creation demonstrates a striking resemblance between Ford's strategy and that of modernisation theorists during the Cold War. ${ }^{4}$ Just as modernisation theorists surmised that the ground-level conditions of developing nations needed to be changed to make them susceptible to Americanisation and modernisation, Grandin terms Ford's ventures a civilising mission with the goal of realising his vision of America in the Amazon basin. Just as modernisation theorists believed that recreating the American way of life and consumer capitalism in developing nations would prevent their turn to communism, Ford believed that the constructive and rationally ordered activity provided by his mass production system 
would stifle radical political activism in the country into which it was transplanted (Grandin, 2010, pp.3-4, 7-8, 54). Joel Wolfe's work provides a Brazilian perspective on Ford's influence in Brazil and its contribution to the country's modernisation, complementing Grandin's analysis. Wolfe holds that from the creation of Ford factories in Brazil 'automobility quickly took on the qualities of an ideology, promising to cure all of Brazil's problems'. He posits that Brazilians saw Ford's project in particular as evidence that modernity could be carved straight out of nature by creating a 'productive, developed region' that could contribute to Brazilian society, and that this assessment was true to Ford's motivations (Wolfe, 2010, pp.27, 84). The importance of Grandin's and Wolfe's works lies not only in their demonstration that Fordism was consciously exported beyond America's borders, but also in their indication that the expansion of Fordist ideas was facilitated through the actions of Ford and his managers. This observation helps to deepen our understanding of how Americanism spread throughout the world during the early twentieth century, illustrating that government actors did not solely spearhead efforts at ideological expansion.

Just as US government officials and modernisation theorists promoted consumer capitalism and the ideology of Americanism as the route to successful development during the Cold War, Mark Rupert's monograph contends that Fordism was transformed from a domestic system to an ideological project during the early twentieth century. It was fairly easy for Fordism to develop in such a manner, Rupert argues, as Ford's conception of the 'American way' was not a vision that was understood to only apply to America, but was expressed with a similar universalism to other hegemonic ideological projects. Like Grandin, Rupert emphasises Ford's belief that all civilisation strove towards a modern future which Fordism could provide through its combination of mass production and mass consumption. For this reason, Rupert holds that Ford understood his mission and that of his managers was not for the 'selfish pursuit of profit', but rather for the 'greater good of mankind'. Certainly, 
Rupert's work demonstrates that Ford's belief appeared to be coming true in the first decades of the twentieth century. The methods used by US firms to improve efficiency and control workers became increasingly attractive for European capitalists who wished to remain competitive with their American rivals. Fordism and Taylorism appealed to both the political left and right in Europe who believed that economic rationalisation would stifle class conflict. Although Rupert maintains that worker resistance eventually undid the Fordist system throughout the 1930s and 1940s, he argues that Fordism laid the foundations for the transnational neoliberal hegemony that was established in the postwar period by uniting the world's leading economies in a quest for greater productivity (Rupert, 1995, pp.65-67, 72, 7577). Rupert makes a convincing case for seeing Fordism as a set of ideas regarding production and management that became subsumed into the ideological framework of Americanism due to their shared idea that the world could best modernise in America's image. His work raises questions of whether this same unity between domestic production methods and national ideology exists elsewhere, and also how those nations that became enamoured with Fordism incorporated this fragment of Americanism into their own ideological frameworks.

As Rupert emphasises, many nations did not need any direct American meddling to become obsessed with Fordism. Thomas Hughes focuses on Fordism's reception in Weimar Germany, principally arguing that Germans admired the conceptual basis of Fordism over its material innovations as representative of the intersection between America's rationalised production systems and its functioning democracy. The former, in particular, appears in Hughes's analysis to define the German understanding of Americanism as a combination of Taylorist scientific management and Fordist mass production. Hughes's work encourages us to view Fordism as a system of concepts and ideas rather than material innovations because European managers understood Fordism in this way. Furthermore, Hughes suggests that 
Weimar attempts to replicate these much sought after elements of the American way of life led to Fordism transforming into a 'political program and an agenda for social change' (Hughes, 2004, pp.284-286). Grandin's and Rupert's analyses demonstrate that this transformation was global, illustrated in his Amazonian development efforts and the activities of his Sociological Department. David Greenstein's recent article on the adoption of Fordism in Soviet Russia during the 1920s adds to our understanding of Fordism's global influence. Greenstein identifies that, paradoxically, Soviet Russians saw Americanism and Bolshevism as mutually compatible, believing that integrating Fordist techniques would allow Bolshevism to overtake American capitalism. He importantly argues that this transfer of ideas was not unidrectional, as previous analyses of American influence abroad suggest, but that Russians helped develop Americanism and Fordism through their migration and encounters with the Ford Motor Company (Greenstein, 2014, pp.259-262, 288-289). The adoption of Fordism in Weimar Germany and Soviet Russia testifies to the international desirability of Americanism in the early twentieth century and reinforces Rupert's understanding of Fordism as an ideological project, albeit one more blurry and contested in its application than previously assumed.

However, not all studies of Fordism's international impact conclude that its reception was favourable. Henry Friedman and Sander Meredeen's work on the Ford Sewing Machinists Strike of 1968 demonstrates an example of Fordism and Americanism becoming a flashpoint for industrial unrest. This strike, 'an explosion of collective consciousness' among women workers at Ford's River Plant in Dagenham, Essex, transformed the nature of industrial relations between Ford's managers and the shopfloor and set into motion the passage of equal pay legislation from the 1970s onwards. Friedman and Meredeen's work provides exceptionally detailed and countervailing managerial and worker perspectives of the strike, a decision uniquely suited to their own personal experiences: at the time of the strike, 
Friedman was a Senior Convenor of Shop Stewards, and conversely Meredeen was a senior member of the Ford Motor Company's Industrial Relations Staff. Their section on the managerial viewpoint emphasises that Ford had developed an early notoriety for 'aggressive management and bad labour relations' stemming from the 'paternalistic and authoritarian' nature of the original Ford industrial creed. Their section on the labour viewpoint similarly sees the Ford industrial creed as resulting from Ford's 'passion for total and autocratic control'. This same ethos, along with Ford's industrial production techniques, was transplanted into British Ford plants from Ford's inauguration as a British company from 1928. Friedman and Meredeen note that American and British workers experienced discontent at similar work conditions, namely that they felt reduced to 'mere appendages of the machine' and reviled the company's 'well-oiled espionage system'. Subsequent industrial action by workers at British Ford plants to oppose these conditions led to Ford becoming 'the commonplace symbol of an industrial society at war' in Britain. This negative association with Americanism and Fordism even extended to the managerial level, as managerial staff received threats from the parent company that American managers would be sent to replace British managers at plants in the UK if they could not temper labour unrest. Several managers resigned as a result due to their discontent at the increasing Americanisation of the British branches (Friedman \& Meredeen, 1980, pp.9-10, 13, 19-22, 27, 32, 40-41, 52). Friedman and Meredeen's study provides a useful case study of Fordism and Americanism being received negatively, and actively resisted, by international audiences during the twentieth century, complementing the works of Grandin, Wolfe, Hughes, and Rupert to develop our understanding of the international reception of Fordism.

The historiography of Fordism has evolved considerably from the approaches taken by the initial histories of Henry Ford and the Ford Motor Company in the early and mid twentieth century. Analyses of the Fordist assembly line have moved away from 
technological minutiae and towards how its underlying principles of efficiency and rationality became pillars of Americanism. Although these studies show that Fordism was culturally and politically appealing to many Americans, the work of labour historians continues to contrast Fordism's rosy ideals with its brutal reality of speedup, deskilling, unemployment, and repressive managerial control in the workplace. Their focus on the worker's experience of Fordism has revealed that, despite the rank-and-file's apparent lack of overt resistance and organisation, they did indeed resist Fordism, though often subtly. These studies should encourage historians to look for further examples of subtle resistance in other contexts to overturn narratives of labour passivity. Similarly, recent works on Fordist capitalism have identified that Fordism's global spread was not solely the result of other countries wishing to imitate America's economic success but rather was tactically manipulated by foreign policy planners as one of the many appendages of Cold War imperialism.

In hindsight, Henry Ford's arrogance at the success of his company appears prescient. Throughout his life, he had seen the successful implementation of Fordist economic principles within America, with his products and the technologies allowing for their mass production becoming mainstays in the global cultural consciousness. Although he had begun to consider how his vision of Americanism, brand of capitalism, and production system could be exported abroad, he did not live to see these same principles become the route to economic regeneration for many countries following the Second World War and their export becoming a central goal of American foreign policy during the Cold War. With all the different ways Fordism has contributed to Americanism, it is only natural that historiographical approaches to Fordism have diversified so dramatically, but there is still much work to be done to form a complete picture of the many dimensions of Fordism and its global impact. Although the rare works on Fordist culture and those exploring Fordism's technological dimensions go to great lengths to demonstrate how the assembly line transformed into a symbol of the new, highly- 
sought after mass production/mass consumption society and a international cultural icon of Americanism, whether embraced or reviled, scholars could do well to investigate cultural and countercultural currents from the 1950s to the 1970s through a Fordist lens to determine the extent to which its principles persisted in American culture, as new technologies rose to prominence and were made the subject of rebellion by counterculture and as nations began to abandon the Fordist capitalism in favour of neoliberalism.

Labour histories and studies of Fordist management have demonstrated Fordism's importance as a formative phase in the development of late twentieth century management and methods of labour organisation and resistance, illustrating that this period of 'consensus' between labour and management proved the ideal opportunity for unionists and executives to engage with American ideology and politics as Fordism became subsumed into them. In turn, Ford's populism, his connection to capitalism, and his influence on Americanism can perhaps be seen as an analogue for Trumpism today. While more focused studies on worker reactions to Fordist management would not go amiss, and would serve to balance out the many studies of Fordism from an upper managerial perspective, perhaps a fruitful avenue of future research would be for scholars to focus on the activity of floor managers within Ford's factories, to delve deeper into their experiences applying the principles of Fordism in their treatment of workers and their understanding of Fordism's importance to Americanism. However, the most promising direction for new research into Fordism lies in embracing the transnational turn further and continuing to investigate the international reception of Fordism, and by extension Americanism. Not only would this continue to unite the two definitions of Fordism, studies of Fordism as a global phenomenon provide a clear example of the interrelation between domestic economic and technological developments and international political and ideological goals. Therefore, it seems prudent to investigate both the export of Fordist principles abroad in the early twentieth century in more depth and the export of Fordism's 
technological and economic predecessors and successors in the same manner, as well as whether those countries adopting Fordist principles exported them as American or attempted to rid their systems of ties to Americanism. In this manner, Fordism can remain useful in helping us understand the process through which present-day globalisation, populism and obsession with technology came to be.

${ }^{1}$ For a detailed examination of the Fordist production processes and technologies, the success of Ford automobiles and the development of the twentieth century automobile market, see Rae (1984) and Rubenstein (2001).

${ }^{2}$ This discussion of literature on Henry Ford deliberately omits the more polemical literature on Ford authored during his lifetime, such as Upton Sinclair's The Flivver King (1937) written at the time of the Congress of Industrial Organization's organising drive.

${ }^{3}$ For works discussing Taylorism and its effects on workplace organisation, see Montgomery (1979) and Nelson (1995).

${ }^{4}$ For works on modernisation theory and strategy as it relates to Americanism, see Adas (2006) and Ekbladh (2011). 


\section{References}

Adas, M. (2006). Dominance by design: technological imperatives and America's civilizing mission. Cambridge, MA: Belknap Press.

Coopey, R., \& McKinlay A. (2010). 'Power without knowledge? Foucault and Fordism, c.1900-50'. Labor History, 51, 107-125. doi:10.1080/00236561003654800

Davis, M. (1986). Prisoners of the American dream: politics and economy in the history of the U.S. working class. London: Verso Editions.

Ekbladh, D. (2011). The great American mission: modernization and the construction of an American world order. Princeton, NJ: Princeton University Press.

Friedman, H., \& Meredeen, S. (1980). The dynamics of industrial conflict: lessons from Ford. London: Croom Helm.

Gartman, D. (1986). Auto slavery: the labor process in the American automobile industry, 1897-1950. New Brunswick, NJ: Rutgers University Press.

Gartman, D. (2009). From autos to architecture: Fordism and architectural aesthetics in the twentieth century. New York, NY: Princeton Architectural Press.

Gordon, D.M., Edwards R., \& Reich, M. (1982). Segmented work, divided workers: the historical transformation of labor in the United States. Cambridge: Cambridge University Press.

Grandin, G. (2010). Fordlandia: the rise and fall of Henry Ford's forgotten jungle city. London: Icon.

Greenstein, D. E. (2014). 'Assembling Fordizm: The Production of Automobiles, Americans, and Bolsheviks in Detroit and Early Soviet Russia'. Comparative Studies in Society and History, 56, 259-289. doi:10.1017/s0010417514000048

Harvey, D. (2005). A brief history of neoliberalism. Oxford: Oxford University Press. 
Heffernan, N. (2000). Capital, class, and technology in contemporary American culture: projecting post-Fordism. London: Pluto Press.

Hounshell, D. (1984). From the American system to mass production, 1800-1932: the development of manufacturing technology in the United States. Baltimore, MD: Johns Hopkins University Press.

Hughes, T. P. (2004). American genesis: a century of invention and technological enthusiasm, 1870-1970. Chicago, IL: University of Chicago Press.

Meyer, S. (1981). The five dollar day: labor management and social control in the Ford Motor Company, 1908-1921. Albany, NY: State University of New York Press.

Montgomery, D. (1979). Workers' Control in America: studies in the history of work, technology, and labor struggles. Cambridge: Cambridge University Press.

Nelson, D. (1995). Managers and Workers: Origins of the Twentieth-Century Factory System in the United States, 1880-1920 (2nd ed.). Madison, WI: University of Wisconsin Press.

Nevins, A., \& Hill, F.E. (1957). Ford: expansion and challenge, 1915-1933. New York, NY: Scribner.

Nye, D. E. (2015). America's Assembly Line. Cambridge, MA: MIT Press.

Rae, J. B. (1984). The American automobile industry. Boston, MA: Twayne Publishers.

Rubenstein, J. M. (2001). Making and selling cars: innovation and change in the U.S. automobile industry. Baltimore, MD: Johns Hopkins University Press.

Rupert, M. (1995). Producing hegemony: the politics of mass production and American global power. Cambridge: Cambridge University Press.

Sward, K. (1948). The legend of Henry Ford. New York, NY: Rinehart \& Company.

Watts, S. (2005). The people's tycoon: Henry Ford and the American century. New York, NY: A.A. Knopf. 
Wilson, J. M., \& McKinlay, A. (2010). 'Rethinking the assembly line: Organisation, performance and productivity in Ford Motor Company c.1908-27'. Business History, 52, 760-778. doi:10.1080/00076791.2010.499425

Wolfe, J. (2010). Autos and progress: the Brazilian search for modernity. Oxford: Oxford University Press. 